\title{
TINGKAT PENGETAHUAN IBU NIFAS \\ TENTANG NUTRISI YANG DAPAT MENINGKATKAN PRODUKSI ASI \\ DI BPS EDI SURYANINGRUM GODEAN SLEMAN YOGYAKARTA
}

\author{
Lisa Novita Sari ${ }^{1}$, Eva Putriningrum ${ }^{1}$ \\ ${ }^{1}$ Program Studi Kebidanan Stikes Jenderal Achmad Yani Yogyakarta, Jl. Ringroad Barat Ambarketawang \\ Gamping Sleman, Telp. (0274) 4342000, Email: vakovedant@yahoo.com
}

\begin{abstract}
Background: In Indonesia, exclusive breastfeeding (a period of 6 months breastfeeding without additional intake) only covered $16.5 \%$ women. In 2013 , Sleman reached a number of $80.62 \%$. The ability to brestfeed exclusively is related to breastmilk production, which also corresponds with mothers' nutritional status. It is necessary for puerperal mothers to have knowlegde about nutrition that increase breastmilk production.

Objective: This study aimed to describe the level of knowledge of puerperal women about nutrition that can increase breastmilk production at BPS Edi Suryaningrum, Godean, Sleman, Yogyakarta.

Methods: This study used descriptive quantitative research methods. Sample were selected with a total sampling, consisted of 44 puerperal women. Data were collected with a set of questionnaire, then analyzed with a univariate analysis.

Results: Respondents varied, with a range of age at 20-35 years old, majority were graduates of high school and unemployed (housewife). Twenty two respondents (50.0\%) had adequate knowledge about nutrition that can increase breastmilk production.
\end{abstract}

Conclusion: The knowledge of puerperal women about nutrition that increase breastmilk production was majority in adequate level.

Keywords: Knowledge of puerperal women, nutrition and breastmilk

\section{PENDAHULUAN}

Masa nifas dimulai dari plasenta lahir dan berakhir ketika alat-alat kandungan kembali seperti keadaan sebelum hamil, masa nifas berlangsung selama 42 hari. ${ }^{(1)}$ Kebijakan nasional mengenai masa nifas mencantumkan beberapa kebijakan yaitu terdapat 4 kali kunjungan masa nifas. Kunjungan pertama 6-8 jam setelah persalinan, kunjungan kedua 6 hari masa nifas, kunjungan ketiga pada waktu 2 minggu masa nifas, dan kunjungan keempat pada waktu 6 minggu masa nifas. ${ }^{(2)}$

Kebutuhan gizi pada masa nifas terutama bila untuk menyusui bayi akan meningkat tiga kali dari kebutuhan biasa. Makanan yang dikonsumsi akan meningkatkan metabolisme dan cadangan dalam tubuh serta produksi ASI. Makanan yang dikonsumsi tersebut harus seimbang dan cukup mengandung karbohidrat, energi, protein, mineral, vitamin, dan air. ${ }^{(3)}$

$$
\text { Peningkatan pemberian }
$$
dipromosikan pemerintah saat ini, karena menyusui sejak dini mempunyai dampak yang positif baik bagi ibu maupun bayi, karena $80 \%$ perkembangan otak anak dimulai sejak dalam kandungan sampai dengan usia 5 tahun yang dikenal dengan masa keemasan. Oleh karena itu diperlukan ASI ekslusif selama 6 bulan dan dapat diteruskan hingga anak usia 2 tahun, dilihat dari komposisi ASI yang banyak mengandung zat gizi, antara lain karbohidrat, 
protein, dan lemak yang banyak dibutuhkan bayi dalam jumlah yang seimbang. ${ }^{(4)}$

Faktor penyebab ketidakberhasilan ASI Ekslusif antara lain seperti ibu yang bekerja di luar rumah, pengeluaran ASI yang sedikit, kurang memahami teknik menyusui, dan yang paling penting adalah kurang mengerti tentang nutrisi yang dapat meningkatkan produksi ASI. ${ }^{(5)}$

Tingkat pengetahuan ibu tentang gizi sangat penting dalam meningkatkan status gizi keluarga terutama balitanya ${ }^{(1)}$. Semakin sering bayi disusui dengan ASI, maka payudara ibu akan semakin terangsang untuk memproduksi ASI yang lebih banyak disertai makan-makanan yang bergizi. ${ }^{(6)}$

Berdasarkan hasil studi pendahuluan di BPS Edi Suryaningrum, dengan melakukan wawancara pada 10 ibu nifas. Didapatkan hasil 7 ibu nifas menyatakan bahwa masa nifas tidak boleh makan amis-amisan seperti daging, ikan telur dan susu, 3 ibu nifas lainnya dapat menjelaskan makanan yang dapat meningkatkan produksi ASI seperti makanan yang mengandung protein, daging, ikan, sayuran hijau, buah-buahan dan kacang-kacangan.

Penelitian ini bertujuan untuk mengetahui gambaran tingkat pengetahuan ibu nifas tentang nutrisi yang dapat meningkatkan produksi ASI di BPS Edi Suryaningrum, Godean.

\section{BAHAN DAN CARA PENELITIAN}

Jenis penelitian ini adalah deskriptif kuantitatif. Populasi dalam penelitian ini adalah semua ibu nifas yang berkunjung di BPS Edi Suryaningrum, Godean, Sleman, Yogyakarta, yaitu sebanyak 44 ibu nifas. Sampel penelitian ini semua populasi berjumlah 44 responden. Pengambilan data primer menggunakan kuesioner tertutup. Analisis data secara deskriptif dinyatakan dengan bilangan persentase.

\section{HASIL DAN PEMBAHASAN}

Tabel 1 Distribusi Karakteristik Responden

\begin{tabular}{lcc}
\hline \multicolumn{1}{c}{ Karakteristik } & F & $\%$ \\
\hline Umur (tahun) & & \\
$18-25$ & 24 & 55 \\
$26-33$ & 12 & 27 \\
$34-41$ & 8 & 18 \\
\hline Pendidikan & & \\
SD & 2 & 5 \\
SMP & 12 & 27 \\
SMU & 27 & 61 \\
D.III & 3 & 7 \\
\hline Pekerjaan & & \\
Tidak bekerja & 32 & 73 \\
Wiraswasta & 9 & 20 \\
Lainnya & 3 & 7 \\
\hline
\end{tabular}

(Sumber : data primer 2015)

Tabel 1 menunjukkan bahwa umur responden sebagian besar adalah 18-25 tahun yaitu 24 responden (55\%). Tingkat pendidikan responden sebagian besar adalah SMU yaitu 27 responden (61\%). Sebagian besar pekerjaan responden adalah tidak bekerja yaitu sebanyak 32 responden (73\%). 
Tabel 2 Distribusi Frekuensi Responden

Berdasarkan Tingkat Pengetahuan Ibu

Nifas Tentang Nutrisi Yang Dapat Meningkatkan Produksi ASI

\begin{tabular}{ccc}
\hline $\begin{array}{c}\text { Tingkat } \\
\text { Pengetahuan }\end{array}$ & $\mathbf{F}$ & $\%$ \\
\hline Baik & 18 & 41 \\
Cukup & 21 & 48 \\
Kurang & 5 & 11 \\
\hline Jumlah & 44 & 100 \\
\hline
\end{tabular}

(Sumber:data primer 2015)

Berdasarkan tabel 2 sebagian besar responden di BPS Edi Suryaningrum Godean, Sleman, Yogyakarta, memiliki pengetahuan tentang nutrisi yang dapat meningkatkan produksi ASI dalam kategori cukup yaitu sebanyak 21 responden (48\%).

Tabel 3 Gambaran Umur Dengan Tingkat Pengetahuan Ibu Nifas Tentang Nutrisi Yang Dapat Meningkatkan Produksi ASI

\begin{tabular}{lcccccccc}
\hline Umur & \multicolumn{2}{c}{ Baik } & \multicolumn{2}{c}{ Cukup } & \multicolumn{2}{c}{ Kurang } & Jumlah \\
& & & & & & & \\
\hline & $\mathrm{F}$ & $\%$ & $\mathrm{~F}$ & $\%$ & $\mathrm{~F}$ & $\%$ & $\mathrm{~F}$ & $\%$ \\
\hline $18-25$ & 12 & 27 & 11 & 25 & 1 & 2 & 24 & 55 \\
$26-33$ & 6 & 14 & 3 & 7 & 3 & 7 & 12 & 27 \\
$34-41$ & 0 & 0 & 7 & 16 & 1 & 2 & 8 & 18 \\
& & & & & & & \\
\hline Jumlah & 17 & 41 & 23 & 48 & 4 & 11 & 44 & 100 \\
\hline
\end{tabular}

Tabel 3 Menunjukkan bahwa sebagian besar responden berumur 18-25 tahun dengan tingkat pengetahuan tentang nutrisi yang dapat meningkatkan produksi ASI dalam kategori baik sebanyak 12 responden (27\%).

Tabel 4 menunjukkan di bawah menunjukkan bahwa sebagian besar responden berpendidikan terakhir SMU dengan tingkat pengetahuan tentang nutrisi yang dapat meningkatkan produksi ASI dalam kategori baik sebanyak 14 responden $(32 \%)$.

Tabel 4 Gambaran Pendidikan Dengan Tingkat Pengetahuan Ibu Nifas Tentang Nutrisi Yang Dapat Meningkatkan Produksi

\begin{tabular}{|c|c|c|c|c|c|c|c|c|}
\hline \multirow{3}{*}{ Pendidikan } & \multicolumn{6}{|c|}{ Pengetahuan } & \multicolumn{2}{|c|}{ Jumlah } \\
\hline & \multicolumn{2}{|c|}{ Baik } & \multicolumn{2}{|c|}{ Cukup } & \multicolumn{2}{|c|}{ Kurang } & & \\
\hline & $\mathrm{F}$ & $\%$ & $\mathrm{~F}$ & $\%$ & $\mathrm{~F}$ & $\%$ & $\mathrm{~F}$ & $\%$ \\
\hline $\mathrm{SD}$ & 0 & 0 & 1 & 2 & 1 & 2 & 2 & 5 \\
\hline SMP & 4 & 9 & 6 & 14 & 2 & 5 & 12 & 27 \\
\hline SMU & 14 & 32 & 11 & 25 & 2 & 2 & 27 & 61 \\
\hline III & 0 & 0 & 3 & 7 & 0 & 0 & 3 & 7 \\
\hline Jumla & 18 & 41 & 21 & 48 & 5 & 11 & 44 & 100 \\
\hline
\end{tabular}

(Sumber : data primer 2015)

Tabel 5 Gambaran Pekerjaan Dengan Tingkat Pengetahuan Ibu Nifas Tentang Nutrisi Yang Dapat Meningkatkan Produksi ASI

Pekerjaan Baik Cukup Kurang Jumlah

\begin{tabular}{ccccccccc}
\hline & $\mathrm{F}$ & $\%$ & $\mathrm{~F}$ & $\%$ & $\mathrm{~F}$ & $\%$ & $\mathrm{~F}$ & $\%$ \\
\hline Tidak & 13 & 30 & 16 & 36 & 3 & 7 & 32 & 73 \\
$\begin{array}{c}\text { bekerja } \\
\begin{array}{c}\text { Wiraswasta } \\
\text { Lainnya }\end{array}\end{array}$ & 4 & 9 & 4 & 9 & 1 & 2 & 9 & 20 \\
\hline Jumlah & 18 & 41 & 21 & 48 & 5 & 11 & 44 & 100 \\
\hline
\end{tabular}

(Sumber : data primer 2015)

Tabel 5 menunjukkan bahwa sebagian besar responden tidak bekerja dengan tingkat pengetahuan tentang nutrisi yang dapat meningkatkan produksi ASI dalam kategori cukup sebanyak 16 responden (36\%).

Hasil penelitian untuk karakteristik responden sebagian besar adalah 18-25 tahun yaitu 24 responden (55\%). Tingkat pendidikan responden sebagian besar adalah SMU yaitu 27 responden (61\%). Sebagian besar responden tidak pekerjaan yaitu sebanyak 32 responden (73\%).

Pengetahuan yang kurang dapat disebabkan karena kurangnya penyuluhan dan informasi oleh tenaga kesehatan dan 
masih beredar dilingkungan masyarakat mitos-mitos tentang larangan makanan yang tidak boleh dikonsumsi ibu nifas. Selain itu orangtua juga berpengaruh terhadap asupan nutrisi yang didapat oleh ibu nifas. Pengetahuan merupakan hasil dari tahu dan terjadi setelah orang melakukan pengindraan terhadap suatu objek tertentu. Pengindraan terjadi melalui pancaindra manusia, yakni pengindraan menghasilkan pengetahuan yang sangat dipengeruhi oleh intensitas perhatian dan persepsi terhadap objek. Sebagian besar pengetahuan manusia diperoleh melalui mata dan telinga. ${ }^{(7)}$

Pengetahuan dipengaruhi oleh beberapa faktor diantaranya faktor internal yang terdiri atas umur, jenis kelamin, pendidikan, pekerjaan, dan eksternal yang terdiri atas lingkungan, sosial budaya, status ekonomi, sumber informasi, dan pengalaman. ${ }^{(8)}$

Berdasarkan hasil penelitian, dapat diketahui bahwa secara keseluruhan tingkat pengetahuan ibu nifas tentang nutrisi yang dapat meningkatkan produksi ASI di BPS Edi Suryaningrum Godean sebagian besar dalam kategori cukup yaitu sebanyak 21 responden (48\%). Pengetahuan yang kurang dapat disebabkan karena kurangnya penyuluhan dan informasi oleh tenaga kesehatan, serta masih banyak beredarnya mitos-mitos tentang larangan makanan yang boleh dikonsumsi oleh ibu nifas dilingkungan masyarakat. Selain itu orangtua juga berpengaruh terhadap asupan nutrisi yang didapat oleh ibu nifas.

Sebagian besar umur responden berada dalam kategori 18-25 tahun yaitu 24 responden (55\%), dengan tingkat pengetahuan tentang nutrisi yang dapat meningkatkan produksi ASI dalam kategori baik sebanyak 12 responden (27\%). Umur merupakan salah satu faktor yang memengaruhi tingkat pengetahuan. Seseorang yang berumur produktif (muda) lebih mudah menerima pengetahuan dibandingkan seseorang yang berumur tidak produktif (lebih dewasa) karena orang dewasa telah memiliki pengalaman yang memengaruhi pola pikir sehingga sulit untuk diubah. ${ }^{(7)}$

Sebagian besar responden adalah berpendidikan terakhir SMU yaitu sebanyak 27 responden (61\%), dengan tingkat pengetahuan tentang nutrisi yang dapat meningkatkan produksi ASI berada dalam kategori baik sebanyak 14 responden (32\%). Pendidikan dapat memengaruhi pengetahuan ibu nifas tentang nutrisi yang dapat meningkatkan produksi ASI, karena semakin tinggi pendidikan, pengetahuan dan kualitasnya akan lebih baik.

Tingkat pendidikan berhubungan dengan daya serap seseorang terhadap informasi. Pendidikan responden yang lebih tinggi menyebabkan kemampuan dalam memahami masalah akan semakin baik. Semakin baik daya serap seseorang maka akan semakin baik pula kemampuan dalam menghadapi 
masalah. Hal ini sesuai dengan teori bahwa pendidikan berarti bimbingan yang diberikan seseorang terhadap perkembangan orang lain menuju ke arah cita-cita tertentu yang menentukan manusia untuk berbuat dan mengisi kehidupan untuk mencapai keselamatan dan kebahagiaan. Pendidikan diperlukan untuk mendapat informasi, misalnya hal-hal yang menunjang kesehatan sehingga dapat meningkatkan kualitas hidup. Pendidikan dapat memengaruhi seseorang termasuk juga perilaku akan pola hidup terutama dalam memotivasi untuk sikap berperan serta dalam pembangunan pada umumnya, semakin tinggi pendidikan seseorang maka akan semakin mudah dalam menerima informasi. ${ }^{(8)}$

Sebagian besar ibu nifas tidak mempunyai pekerjaan yaitu sebesar 32 responden (73\%), dengan tingkat pengetahuan tentang nutrisi yang dapat meningkatkan produksi ASI berada dalam kategori cukup sebanyak 16 responden (36\%). Hal ini sesuai dengan teori bahwa pekerjaan mempunyai pengaruh pada pengetahuan seseorang. Orang-orang yang bekerja biasanya mempunyai wawasan yang lebih luas dibandingkan orang yang tidak bekerja. Sumber informasi baru bagi mereka yang bekerja akan lebih banyak dari pada mereka yang tidak bekerja. Mereka bisa mendapatkan informasi di jalan, tempat kerja, dan lain sebagainya. ${ }^{(7)}$

Pekerjaan memengaruhi tingkat pengetahuan tentang gizi, karena pekerjaan dapat membuat seseorang memperoleh pengalaman dan pengetahuan baik secara langsung maupun tidak langsung. Pergaulan lingkungan sosial dalam pekerjaan akan memberikan dampak positif dan negatif. Seseorang yang bergaul dengan orang-orang yang mempunyai pengetahuan tinggi maka secara langsung maupun tidak langsung pengetahuan yang dimilikinya akan bertambah begitu sebaliknya. ${ }^{(9)}$

\section{KESIMPULAN}

Kesimpulan yang dapat diperoleh dari penelitian ini adalah dari 44 ibu nifas, sebagian besar berumur 18-25 tahun yaitu 24 responden (55\%). Tingkat pendidikan responden sebagian besar adalah SMU yaitu 27 responden (61\%). Sebagian besar pekerjaan responden adalah tidak bekerja yaitu sebanyak 32 responden (73\%). Tingkat pengetahuan ibu nifas tentang nutrisi yang dapat meningkatkan produksi ASI di BPS Edi Suryaningrum Godean, Sleman, Yogyakarta sebagian besar memiliki pengetahuan kategori cukup yaitu sebanyak 21 responden (48\%). Saran bagi tenaga kesehatan lebih meningkatkan pemberian konseling pada ibu nifas tentang nutrisi-nutrisi yang dapat meningkatkan produksi ASI, serta lebih aktif memberikan penyeluhan secara umum di masyarakat terutama tentang mitos-mitos larangan makanan yang dikonsumsi ibu nifas.

\section{KEPUSTAKAAN}

1. Ambarwati, ER dan Wulandari, D. 
Asuhan kebidanan nifas. Yogyakarta mitra cendekia press. 2010.

2. Nugroho. ASI dan Tumor Payudara. Yogyakarta: Nuha Medika. 2011.

3. Proverawati dan Asfuah. Buku Ajar Gizi untuk Kebidanan. Yogyakarta: Nuha Medika. 2012.

4. Proverawati, A dan Rahmawati, D. Kapita Selecta ASI dan Menyusui. Yogyakarta: Nuha Medika. 2010.

5. Maga. Faktor Determinan Produksi ASI padalbu Menyusui di Pukesmas Telaga Jaya Kabutaten Gorontalo Provinsi Gorontalo. Jurnal Kesehatan. 2012.

6. Syafrudin. Untaian Materi Penyuluhan KIA (Kesehatan Ibu dan Anak). Jakarta: Trans Info Media. 2011.

7. Notoadmodjo. Promosi Kesehatan dan IImu Perilaku. Jakarta: Rineka Cipta. 2007.

8. Arikunto, S. Prosedur penelitian suatu pendekatan praktik. Jakarta: Rineka Cipta. 2010.

9. Mubarok, W.I. Promosi Kesehatan utuk Kebidanan. Jakarta: Salemba Medika. 2011. 